\title{
Net Irrigation Requirements for Florida Turfgrass Lawns: Part 1 - Report of Gathered Weather Data and Quality Check ${ }^{1}$
}

\author{
Consuelo C. Romero and Michael D. Dukes²
}

\section{Introduction}

Turfgrasses are used in urban areas to provide multiple benefits to society and the environment. They cover millions of acres of home lawns, commercial properties, roadsides, parks, etc. But an important question is whetherturfgrasses are properly managed. Many critics emphasize that turfgrasses demand too much urban water in a time when water resources are scarce. While indoor water use remains fairly constant throughout the year, outdoor water use increases during the spring and summer. Flattening the peak demand is an objective of water agencies (Beard and Kenna 2006). Better irrigation management would result in less fertilizer and pesticide use, which would be better for the environment.

Urban landscape irrigation is one of the largest growing water use sectors in Florida. The state's Water Management Districts have been working collectively to find ways to assist urban water users to irrigate more efficiently and to enhance planning and regulatory programs in order to conserve water. There is adequate research information to make specific recommendations, such as the specific cultural practices or systems approaches that could be applied to decrease turfgrass water use. Those recommendations could be used immediately to conserve water and maintain turfgrass quality and its functional benefits to society.
The calculation of net irrigation requirements for turfgrass is essential for determining water allocation and can help to determine irrigation scheduling. This series of publications explains the process of estimating net irrigation requirements for Florida turfgrasses. The process used here gives a long-term (30-year) historical analysis of turfgrass monthly net irrigation requirements. The first article in the series explains how the weather data were gathered and checked for quality; the second article shows the calculation of evapotranspiration for selected sites throughout the state (plus one in Alabama, to cover the west side of the Florida Panhandle); and the third and final article outlines the results of the net irrigation estimation. Since Florida's urban landscape water demand is expected to grow considerably over the next few decades, the use of current information in terms of turfgrass irrigation needs will provide urban irrigators with information to help them reduce water volumes applied and conserve water.

Weather inputs needed to calculate either reference evapotranspiration $\left(\mathrm{ET}_{\mathrm{o}}\right.$ ) or to estimate irrigation using a soil water balance include air temperature, solar radiation, wind speed, and precipitation. The accuracy of the calculated $\mathrm{ET}_{\mathrm{o}}$ depends on the quality of the weather data, which requires good quality control and assurance procedures in order to get accurate and representative $\mathrm{ET}_{\mathrm{o}}$ (Allen 2008). If some weather data are missing or erroneous, then it

1. This document is AE480, one of a series of the Agricultural and Biological Engineering Department, Florida Cooperative Extension Service, Institute of Food and Agricultural Sciences, University of Florida. Original publication date August 2011. Visit the EDIS website at http://edis.ifas.ufl.edu.

2. Consuelo C. Romero, assistant-in research scientist, Agricultural and Biological Engineering Department, and Michael D. Dukes, professor, Agricultural and Biological Engineering Department; Florida Cooperative Extension Service, Institute of Food and Agricultural Sciences, University of Florida, Gainesville, FL 32611. 
may be possible to estimate them in order to apply the $\mathrm{ET}_{\mathrm{o}}$ equation. For example, in situations where solar radiation, humidity, or any other weather parameter is missing for long periods of time, data can be taken from a nearby weather station (Allen et al. 2005). Allen et al. (2005) provide a series of equations for estimating missing values of humidity, solar radiation, wind speed, and maximum and minimum temperatures.

\section{Objective}

The objective of this study was to check the quality of 30 years of weather data at ten different locations in Florida and one in Alabama.

\section{Gathering Meteorological Data}

Daily measured meteorological data for a 30-year (January 1, 1980 - December 31, 2009) period were gathered from 11 weather stations located at airports in major cities in or near Florida to represent climate conditions from the Panhandle down to South Florida (Figure 1). Additional rainfall data from 7 rainfall stations (Plant City, St. Leo, Hillsborough River State Park, Brooksville, Tarpon Springs, St. Petersburg, and Inverness) within the Southwest Florida Water Management District (SWFWMD) will be used to provide rainfall spatial variability for sites within the District. Those sites within the SWFWMD will then be used for water balances to estimate net irrigation requirements for turfgrass. Data for each weather station was obtained from the National Climatic Data Center (NCDC) (USDC 2009). Daily measured meteorological parameters included maximum and minimum temperature, average dew point temperature, average wind speed, and total precipitation. Daily average solar radiation values were estimated based on Hargreaves and Samani's (1982) equation as presented by Allen (1997), which is based on temperatures and incorporates a correction factor $\left(\mathrm{K}_{\mathrm{r}}\right)$ based on the regional location of each weather station:

$$
\mathrm{R}_{\mathrm{s}}=\mathrm{K}_{\mathrm{r}}\left(\mathrm{T}_{\max }-\mathrm{T}_{\min }\right)^{0.5} \mathrm{R}_{\mathrm{a}}
$$

where $\mathrm{T}_{\max }$ and $\mathrm{T}_{\min }=$ mean daily maximum and minimum air temperature $\left({ }^{\circ} \mathrm{C}\right)$, and $\mathrm{R}_{\mathrm{a}}=$ extraterrestrial radiation. Allen et al. (2005) recommended using $\mathrm{K}_{\mathrm{r}}=0.16$ for interior locations and $\mathrm{K}_{\mathrm{r}}=0.19$ for coastal locations. Hargreaves and Samani (1982) defined an interior location as one with weather patterns dominated by a large landmass, whereas a coastal location was one with weather patterns dominated by close proximity to a large body of water.
The weather data were collected at airports that have substantial non-vegetative fetch and were prone to the heat island effect, which typically creates an arid or semiarid condition for the area. Because of these characteristics, all sites were checked for arid conditions. Sites can be considered arid if daily dew point temperature consistently deviates more than $3-4^{\circ} \mathrm{C}$ less than the daily minimum temperature (Allen 1996). If data from a site indicates that it is arid, the Simplified Aridity Adjustment can be used to correct air and dew point temperatures to reflect weather data collection under well-watered conditions (Allen 1996). To prevent aridity, measurements should be taken above an extensive surface of green grass that is uniform in height, actively growing, completely shading the ground, and adequately watered (Allen et al. 1998).

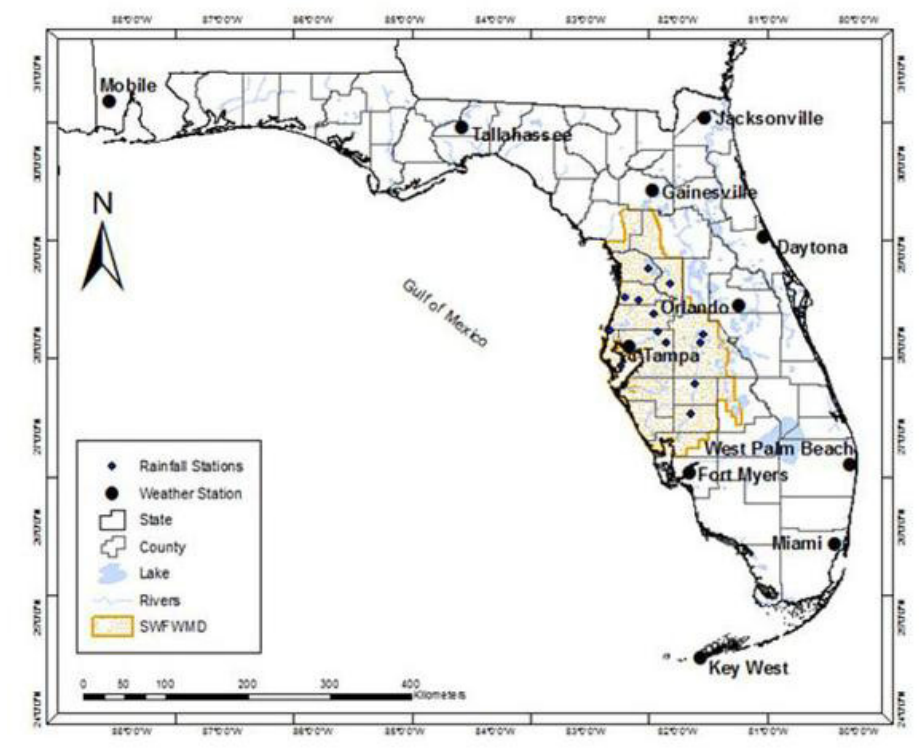

Figure 1. Map showing the locations of weather stations (large dots) and rain gauges (small dots).

\section{Data Quality Check}

Data quality checks were completed for air temperature, wind speed, dew point temperature, solar radiation, and rainfall. The measured data was checked for completeness and quality assurance. It is important that all data are screened, but it is particularly important that solar radiation data are accurate since this is the most sensitive input for the calculation of $\mathrm{ET}_{\mathrm{o}}$ under humid conditions (Irmak et al. 2006). Weather data were screened according to the following procedures as outlined by Allen et al. (2005):

- Weather measurements should be made at or converted to $2 \mathrm{~m}(6.6 \mathrm{ft})$ height. 
- Average daily wind speeds should be between 0.89-2.23 $\mathrm{m} \mathrm{s}^{-1}(2-5 \mathrm{mph})$.

- In a typical humid climate, solar radiation values should not exceed the clear sky solar radiation envelope.

- Scattered missing values were replaced by an average of the values from the day before and the day after.

- For longer periods with missing values, data from close weather stations were used to complete the corresponding information.

\section{Results}

Records of 30 years (1980-2009) of meteorological data for Daytona, Fort Myers, Gainesville, Jacksonville, Key West, Miami, Orlando, Tallahassee, Tampa, West Palm Beach, and Mobile, Alabama, were obtained from NCDC (USDC 2009) (Table 1). This 30-year climatological normal period (as defined by the National Weather Service) was selected because it was the most current group of consecutive years made available through NCDC that included all of the meteorological parameters needed to estimate $\mathrm{ET}_{\mathrm{o}}$ at all of the chosen locations. The data quality check showed that less than $0.01 \%$ of the total data for most meteorological parameters were missing. The percentage of data missing for rainfall was around $1 \%$ of the total data, except for Fort Myers where the number of consecutive days with no rainfall data reached 1,078 . In this specific case, rainfall data was taken from the Naples rainfall database to replace this gap (Table 2). Weather characteristics of the data sets are presented in Tables 3 and 4 . Figures 2 through 5 show the results of three sites (Jacksonville, Orlando, and Miami) that were used as representative cities for North, Central, and South Florida, respectively. Cities located near these representative cities showed similar trends when analyzing the different meteorological parameters.

Table 1. Location and elevation of weather stations in Florida and Mobile, Alabama.

\begin{tabular}{|l|c|c|c|}
\hline \multicolumn{1}{|c|}{ Weather station } & Latitude ( ${ }^{\circ}$ ) & Longitude ( ${ }^{\circ}$ ) & Elevation (m a.s.I.) \\
\hline Tallahassee Regional Airport & 30.39 & 84.35 & 16.8 \\
\hline Jacksonville International Airport & 30.49 & 81.69 \\
\hline Gainesville Regional Airport & 29.69 & 82.28 & 7.9 \\
\hline Daytona Beach International Airport & 29.17 & 81.07 & 37.5 \\
\hline Orlando International Airport & 28.42 & 81.32 & 27.4 \\
\hline Tampa International Airport & 27.96 & 82.54 & 5.8 \\
\hline Fort Myers Page Field Airport & 26.58 & 81.87 & 4.6 \\
\hline W. Palm Beach International Airport & 26.68 & 80.10 & 5.8 \\
\hline Miami International Airport & 25.78 & 80.32 & 8.8 \\
\hline Key West International Airport & 24.55 & 81.75 & 1.2 \\
\hline Mobile Regional Airport & 30.69 & 88.25 & 65.5 \\
\hline
\end{tabular}

Table 2. Percentage (\%) of missing values of total database. Total number of records per weather parameter was 10,950.

\begin{tabular}{|c|c|c|c|c|}
\hline & Max. Temp. & Min. Temp. & Dew Temp. & Rainfall \\
\hline Location & \multicolumn{4}{|c|}{$\%$ missing values } \\
\hline Mobile & - & - & - & 0.63 \\
\hline Tallahassee & - & - & - & 0.47 \\
\hline Jacksonville & 0.02 & 0.02 & 0.01 & 1.49 \\
\hline Gainesville & - & - & 0.01 & 0.69 \\
\hline Daytona & 0.01 & 0.01 & 0.01 & 0.68 \\
\hline Orlando & - & - & - & 0.58 \\
\hline Tampa & - & - & - & 0.11 \\
\hline Fort Myers & - & - & - & 9.84 \\
\hline West Palm Beach & - & - & - & 0.63 \\
\hline Miami & - & - & - & 0.25 \\
\hline Key West & - & 0.01 & 0.01 & 0.47 \\
\hline
\end{tabular}




\section{Analysis of Meterological}

\section{Parameters}

\section{Air Temperature}

Daily maximum and minimum temperatures were plotted against the day of the year (Figure 2). There were no obvious erroneous daily temperature values. For all locations, mean daily maximum temperature for the 30 -year period ranged from $25.9^{\circ} \mathrm{C}\left(78.5^{\circ} \mathrm{F}\right)$ in Mobile to $29.2^{\circ} \mathrm{C}\left(84.6^{\circ} \mathrm{F}\right)$ in Miami. Mean daily minimum temperature ranged from $12.9^{\circ} \mathrm{C}\left(55.3^{\circ} \mathrm{F}\right)$ in Tallahassee to $22.6^{\circ} \mathrm{C}\left(72.6^{\circ} \mathrm{F}\right)$ in Key West.

\section{Wind Velocity}

Average daily wind speed $\left(\mathrm{U}_{2}\right)$ was plotted against day of the year (Figure 3). During the quality control screening procedures, it was found that the average wind speed at all sites exceeded the threshold for concern of $5 \mathrm{mi} \mathrm{h}^{-1}$ (Allen et al. 1998) at least 50\% of the time as seen in Figure 3. Through detailed investigation of the sites, including photos of the stations, it was determined that the wind velocity was measured at $32 \mathrm{ft}$ height, excluding Fort Myers and Tampa, which were measured at $26 \mathrm{ft}$ height. Wind velocity data for all sites were adjusted to $6.5 \mathrm{ft}$ accordingly by standard methods (Allen et al. 1998). Mean daily average wind speed

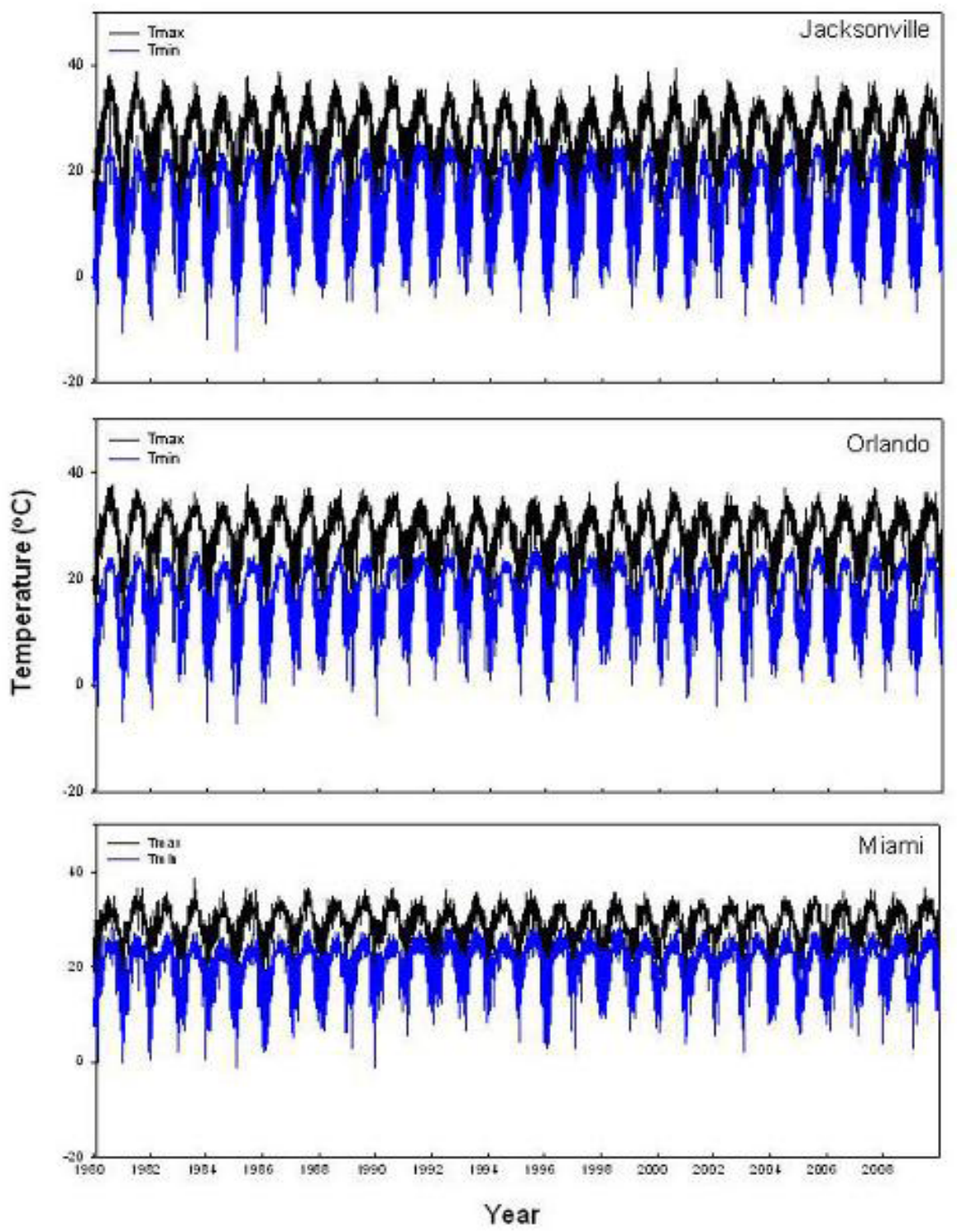

Figure 2. Daily maximum and minimum temperatures for the 30-year period (1980-2009) of weather station data records. 
at $6.5 \mathrm{ft}$ for the 30 -year period ranged from $4.2 \mathrm{mi} \mathrm{h}^{-1}$ in Tallahassee to $7.7 \mathrm{mi} \mathrm{h}^{-1}$ in Key West. Weather stations located closer to the coast had higher wind speeds than those located toward the interior.

\section{Solar Radiation}

Estimated daily average solar radiation $\left(\mathrm{R}_{\mathrm{s}}\right)$ and the computed clear sky solar radiation $\left(\mathrm{R}_{\mathrm{so}}\right)$ were plotted against the day of the year (Figure 4). Daily values of $\mathrm{R}_{\mathrm{so}}$ were calculated as a function of the station elevation extraterrestrial radiation $\left(\mathrm{R}_{\mathrm{a}}\right.$, the amount of solar radiation received at the top of the earth's atmosphere) using the procedures given by Allen et al. (1998). Solar radiation appeared reasonable and generally did not exceed the $\mathrm{R}_{\mathrm{so}}$ envelope as recommended by Allen et al. (1998), and the relationship between the two variables showed similar trends throughout the years. All locations, except Key West and Orlando, had no more than five $\mathrm{R}_{\mathrm{s}}$ values that exceeded $\mathrm{R}_{\mathrm{so}}$. Since the $\mathrm{R}_{\mathrm{s}}$ data values were derived from air temperature, a significant difference between minimum and maximum temperatures in a day would cause these high $\mathrm{R}_{s}$ values. These temperature differences could be due to very clear sky conditions, resulting in higher air temperatures during the day and relatively lower air temperatures during
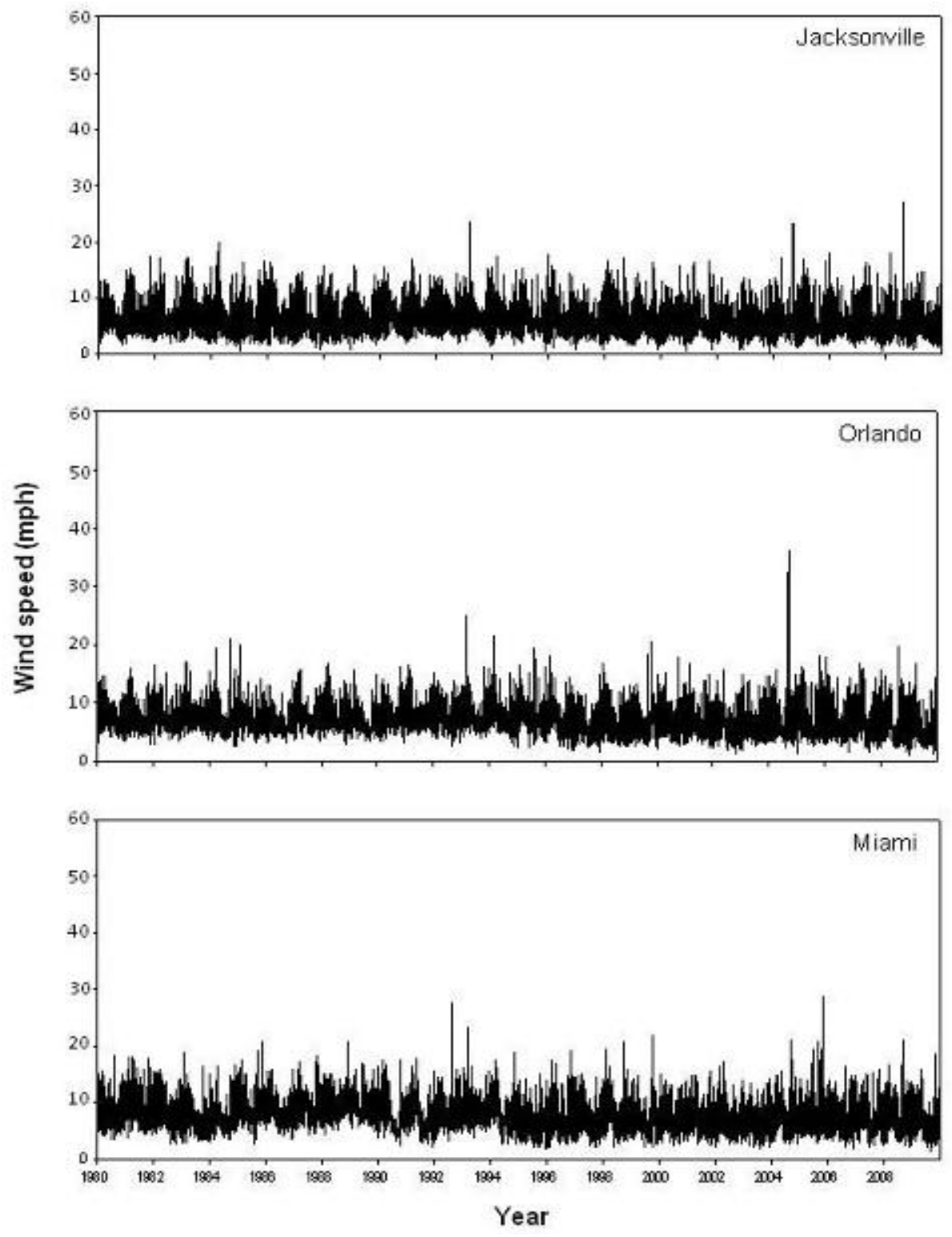

Figure 3. Average daily wind speed at $32 \mathrm{ft}$ height for the 30 -year period (1980-2009) of weather station data records. 
the night (Allen et al. 2005). Mean daily average $\mathrm{R}_{\mathrm{s}}$ ranged from 17.9 $\mathrm{MJ} \mathrm{m}^{-2} \mathrm{~d}^{-1}$ in Miami to $20.0 \mathrm{MJ} \mathrm{m}^{-2} \mathrm{~d}^{-1}$ in Fort Myers.

\section{Dew Point Temperature}

In a humid climate, $\mathrm{T}_{\text {dew }}$ should equal $\mathrm{T}_{\min }$ most days. For arid or semiarid regions a difference of $2-4^{\circ} \mathrm{C}$ is typical (Allen et al. 2005). Although $\mathrm{T}_{\text {dew }}$ deviated more than $3-4^{\circ} \mathrm{C}$ than $\mathrm{T}_{\min }$ on some days for all sites, the long-term (30 years) daily average difference between $\mathrm{T}_{\text {min }}$ and $\mathrm{T}_{\text {dew }}$ was less than $3^{\circ} \mathrm{C}$ for all sites (Table 4). This demonstrates the presence of very humid periods in Florida.

\section{Rainfall}

Cumulative annual rainfall was plotted against the year (Figure 5). For all locations, average annual rainfall for the 30 -year period ranged from 41.7 inches in Key West to 69.6 inches in Mobile. The average annual rainfall for the 7 rainfall stations within the SWFWMD was 52.8 inches. Error bars in Figure 6 represent the variability within these 7 rainfall stations.

\section{Summary}

Thirty years of meteorological data for sites in Florida and one in Alabama were evaluated using quality check
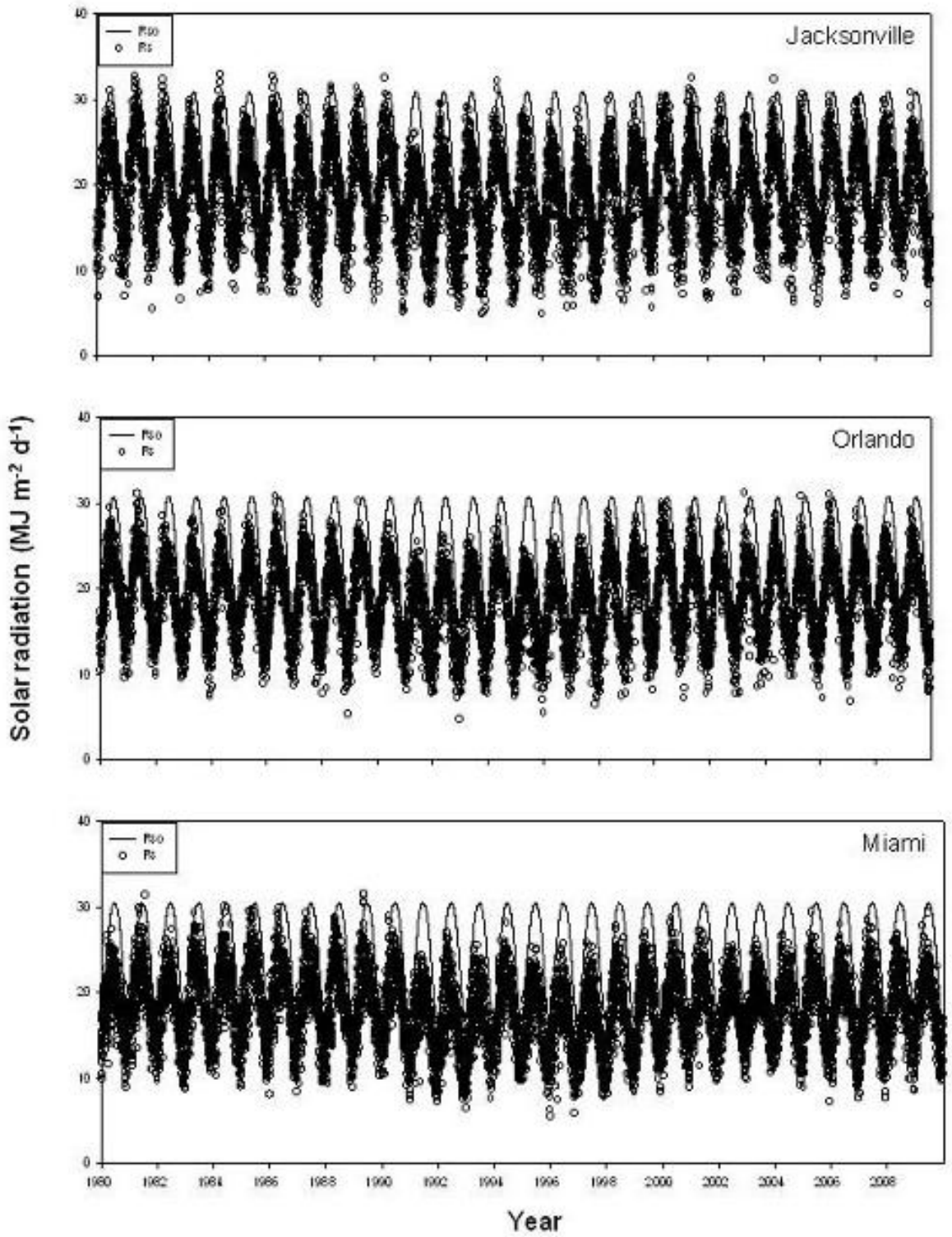

Figure 4. Average daily solar radiation $\left(R_{s}\right)$ and clear sky solar radiation $\left(R_{s o}\right)$ for the 30-year period (1980-2009) of weather station data records. 
Table 3. Values of daily weather parameters (except for rainfall) for the 30-year period (1980-2009) of weather station data records.

\begin{tabular}{|c|c|c|c|c|c|c|c|}
\hline \multirow[b]{2}{*}{ Locations } & \multicolumn{7}{|c|}{ Meteorological parameters } \\
\hline & $\begin{array}{c}T \max \\
\left({ }^{\circ} \mathrm{C}\right)\end{array}$ & $\begin{array}{c}T \min \\
\left({ }^{\circ} \mathrm{C}\right)\end{array}$ & $\begin{array}{c}\text { T dew } \\
\left({ }^{\circ} \mathrm{C}\right)\end{array}$ & $\begin{array}{c}\text { S. Rad. } \\
\left(\mathrm{MJ} \mathrm{m}^{-2} \mathrm{~d}^{-1}\right)\end{array}$ & $\begin{array}{c}\mathrm{U}_{2} \text { at } 32 \mathrm{ft} \\
\left(\mathrm{m} \mathrm{s}^{-1}\right)\end{array}$ & $\begin{array}{c}\mathrm{U}_{2} \text { at } 6.5 \mathrm{ft} \\
\left(\mathrm{m} \mathrm{s}^{-1}\right)\end{array}$ & $\begin{array}{c}\text { Rainfall } \\
\left.\text { (in } y^{-1}\right)\end{array}$ \\
\hline $\begin{array}{l}\text { Mobile } \\
\text { Mean } \\
\text { Max } \\
\text { Min }\end{array}$ & $\begin{array}{l}25.9 \\
40.6 \\
-2.8\end{array}$ & $\begin{array}{c}13.7 \\
27.7 \\
-16.1\end{array}$ & $\begin{array}{c}13.9 \\
26.5 \\
-20.4\end{array}$ & $\begin{array}{c}18.2 \\
32.2 \\
4.3\end{array}$ & $\begin{array}{c}3.5 \\
15.2 \\
0.6\end{array}$ & $\begin{array}{c}2.6 \\
11.4 \\
0.4\end{array}$ & $\begin{array}{l}69.6 \\
94.6 \\
45.7\end{array}$ \\
\hline $\begin{array}{l}\text { Tallahassee } \\
\text { Mean } \\
\text { Max } \\
\text { Min }\end{array}$ & $\begin{array}{l}27.2 \\
39.4 \\
-2.2\end{array}$ & $\begin{array}{c}12.9 \\
27.2 \\
-14.4\end{array}$ & $\begin{array}{c}14.0 \\
25.7 \\
-20.1\end{array}$ & $\begin{array}{c}18.5 \\
33.1 \\
3.4\end{array}$ & $\begin{array}{l}2.5 \\
9.5 \\
0.0\end{array}$ & $\begin{array}{l}1.9 \\
7.1 \\
0.0\end{array}$ & $\begin{array}{l}61.5 \\
93.2 \\
44.1\end{array}$ \\
\hline $\begin{array}{l}\text { Jacksonville } \\
\text { Mean } \\
\text { Max } \\
\text { Min }\end{array}$ & $\begin{array}{l}26.9 \\
39.4 \\
-1.1\end{array}$ & $\begin{array}{c}14.1 \\
28.3 \\
-13.9\end{array}$ & $\begin{array}{c}15.2 \\
26.2 \\
-20.8\end{array}$ & $\begin{array}{c}18.7 \\
32.9 \\
4.9\end{array}$ & $\begin{array}{c}3.0 \\
13.5 \\
0.0\end{array}$ & $\begin{array}{c}2.3 \\
10.1 \\
0.0\end{array}$ & $\begin{array}{l}53.3 \\
75.6 \\
32.2\end{array}$ \\
\hline $\begin{array}{l}\text { Gainesville } \\
\text { Mean } \\
\text { Max } \\
\text { Min }\end{array}$ & $\begin{array}{c}27.3 \\
42.2 \\
1.1\end{array}$ & $\begin{array}{c}14.6 \\
28.0 \\
-12.1\end{array}$ & $\begin{array}{c}15.3 \\
26.1 \\
-16.1\end{array}$ & $\begin{array}{c}18.8 \\
34.5 \\
4.6\end{array}$ & $\begin{array}{c}2.8 \\
12.0 \\
0.1\end{array}$ & $\begin{array}{l}2.1 \\
9.0 \\
0.1\end{array}$ & $\begin{array}{l}46.2 \\
63.3 \\
33.3\end{array}$ \\
\hline $\begin{array}{l}\text { Daytona } \\
\text { Mean } \\
\text { Max } \\
\text { Min }\end{array}$ & $\begin{array}{c}27.4 \\
38.8 \\
3.9\end{array}$ & $\begin{array}{l}16.5 \\
28.1 \\
-9.4\end{array}$ & $\begin{array}{c}16.5 \\
26.2 \\
-16.5\end{array}$ & $\begin{array}{c}19.4 \\
35.1 \\
4.4\end{array}$ & $\begin{array}{c}3.3 \\
18.3 \\
0.3\end{array}$ & $\begin{array}{c}2.5 \\
13.7 \\
0.2\end{array}$ & $\begin{array}{l}47.4 \\
70.6 \\
28.7\end{array}$ \\
\hline $\begin{array}{l}\text { Orlando } \\
\text { Mean } \\
\text { Max } \\
\text { Min }\end{array}$ & $\begin{array}{c}28.7 \\
38.3 \\
5.6\end{array}$ & $\begin{array}{l}16.8 \\
26.7 \\
-7.2\end{array}$ & $\begin{array}{c}16.9 \\
25.9 \\
-13.0\end{array}$ & $\begin{array}{c}18.5 \\
31.2 \\
4.6\end{array}$ & $\begin{array}{c}3.6 \\
18.1 \\
0.5\end{array}$ & $\begin{array}{c}2.7 \\
13.5 \\
0.3\end{array}$ & $\begin{array}{l}52.1 \\
70.0 \\
30.8\end{array}$ \\
\hline $\begin{array}{l}\text { Tampa } \\
\text { Mean } \\
\text { Max } \\
\text { Min }\end{array}$ & $\begin{array}{c}28.3 \\
37.8 \\
5.6\end{array}$ & $\begin{array}{l}17.6 \\
28.3 \\
-7.2\end{array}$ & $\begin{array}{c}17.3 \\
26.6 \\
-13.2\end{array}$ & $\begin{array}{c}19.5 \\
32.8 \\
6.0\end{array}$ & $\begin{array}{c}3.2 \\
13.0 \\
0.0\end{array}$ & $\begin{array}{c}2.5 \\
10.1 \\
0.0\end{array}$ & $\begin{array}{l}48.4 \\
68.9 \\
31.3\end{array}$ \\
\hline $\begin{array}{l}\text { West Palm Beach } \\
\text { Mean } \\
\text { Max } \\
\text { Min }\end{array}$ & $\begin{array}{c}28.8 \\
38.9 \\
5.0\end{array}$ & $\begin{array}{l}19.7 \\
28.3 \\
-5.0\end{array}$ & $\begin{array}{l}18.8 \\
26.0 \\
-7.9\end{array}$ & $\begin{array}{c}18.2 \\
32.2 \\
5.8\end{array}$ & $\begin{array}{c}4.3 \\
18.0 \\
0.2\end{array}$ & $\begin{array}{c}3.2 \\
13.4 \\
0.1\end{array}$ & $\begin{array}{l}62.2 \\
90.0 \\
39.0\end{array}$ \\
\hline $\begin{array}{l}\text { Fort Myers } \\
\text { Mean } \\
\text { Max } \\
\text { Min }\end{array}$ & $\begin{array}{c}29.6 \\
43.3 \\
9.0\end{array}$ & $\begin{array}{l}18.7 \\
29.4 \\
-2.8\end{array}$ & $\begin{array}{c}18.2 \\
26.6 \\
-11.4\end{array}$ & $\begin{array}{c}20.0 \\
34.6 \\
6.0\end{array}$ & $\begin{array}{c}3.3^{*} \\
12.4 \\
0.0\end{array}$ & $\begin{array}{l}2.5 \\
9.6 \\
0.0\end{array}$ & $\begin{array}{l}56.7 \\
84.6 \\
33.2\end{array}$ \\
\hline $\begin{array}{l}\text { Miami } \\
\text { Mean } \\
\text { Max } \\
\text { Min }\end{array}$ & $\begin{array}{c}29.2 \\
39.2 \\
7.2\end{array}$ & $\begin{array}{l}20.7 \\
28.9 \\
-1.1\end{array}$ & $\begin{array}{l}19.2 \\
26.3 \\
-5.2\end{array}$ & $\begin{array}{c}17.9 \\
31.5 \\
5.4\end{array}$ & $\begin{array}{c}3.9 \\
14.4 \\
0.6\end{array}$ & $\begin{array}{c}2.9 \\
10.8 \\
0.5\end{array}$ & $\begin{array}{l}62.5 \\
85.0 \\
43.6\end{array}$ \\
\hline $\begin{array}{l}\text { Key West } \\
\text { Mean } \\
\text { Max } \\
\text { Min }\end{array}$ & $\begin{array}{l}28.6 \\
39.4 \\
11.7\end{array}$ & $\begin{array}{c}22.6 \\
31.0 \\
2.1\end{array}$ & $\begin{array}{l}20.5 \\
27.2 \\
-0.9\end{array}$ & $\begin{array}{c}18.3 \\
35.1 \\
5.8\end{array}$ & $\begin{array}{c}4.6 \\
20.6 \\
0.3\end{array}$ & $\begin{array}{c}3.5 \\
15.4 \\
0.2\end{array}$ & $\begin{array}{l}41.7 \\
63.6 \\
24.9\end{array}$ \\
\hline
\end{tabular}



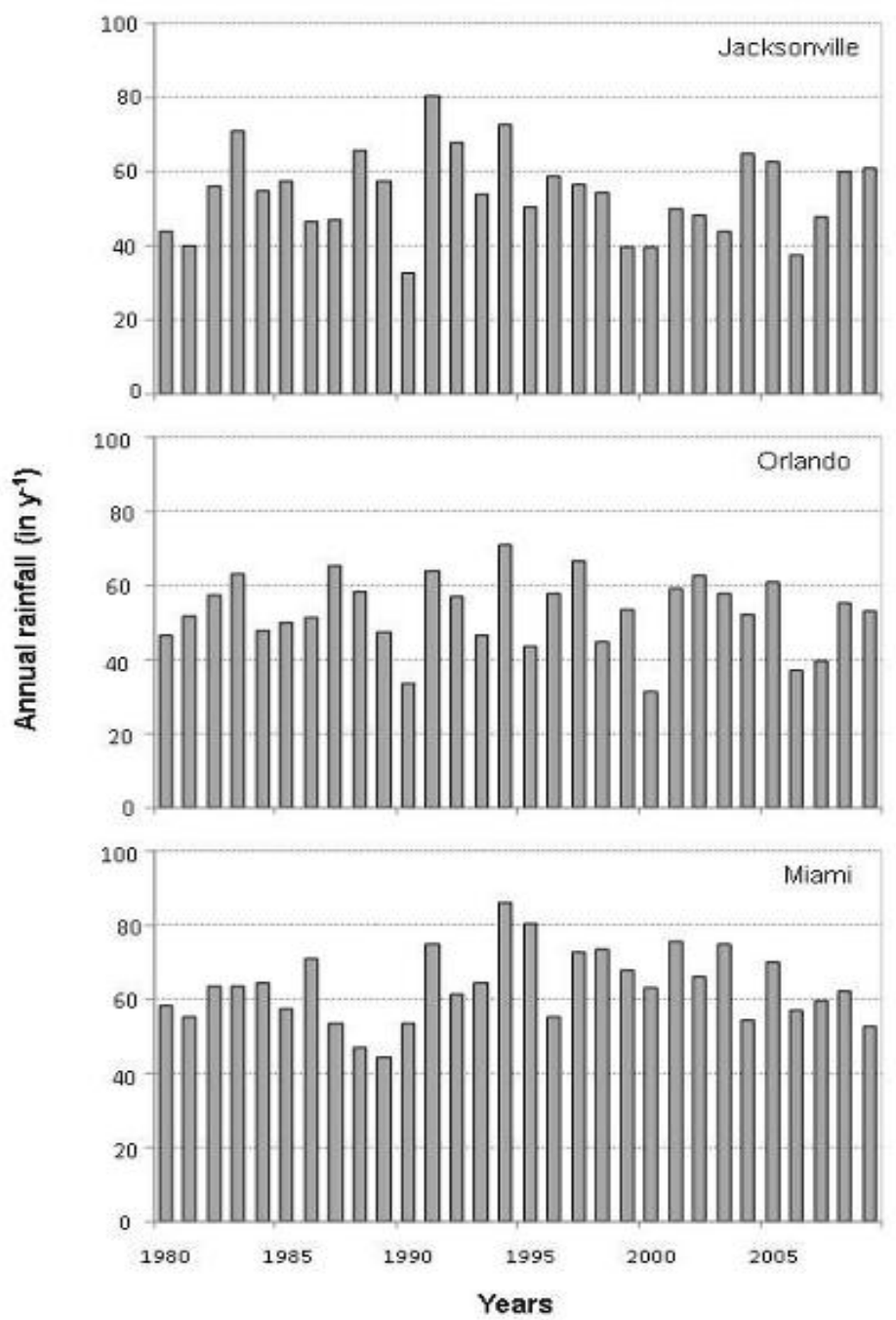

Figure 5. Annual cumulative rainfall for the 30-year period (19802009) of weather station data records.

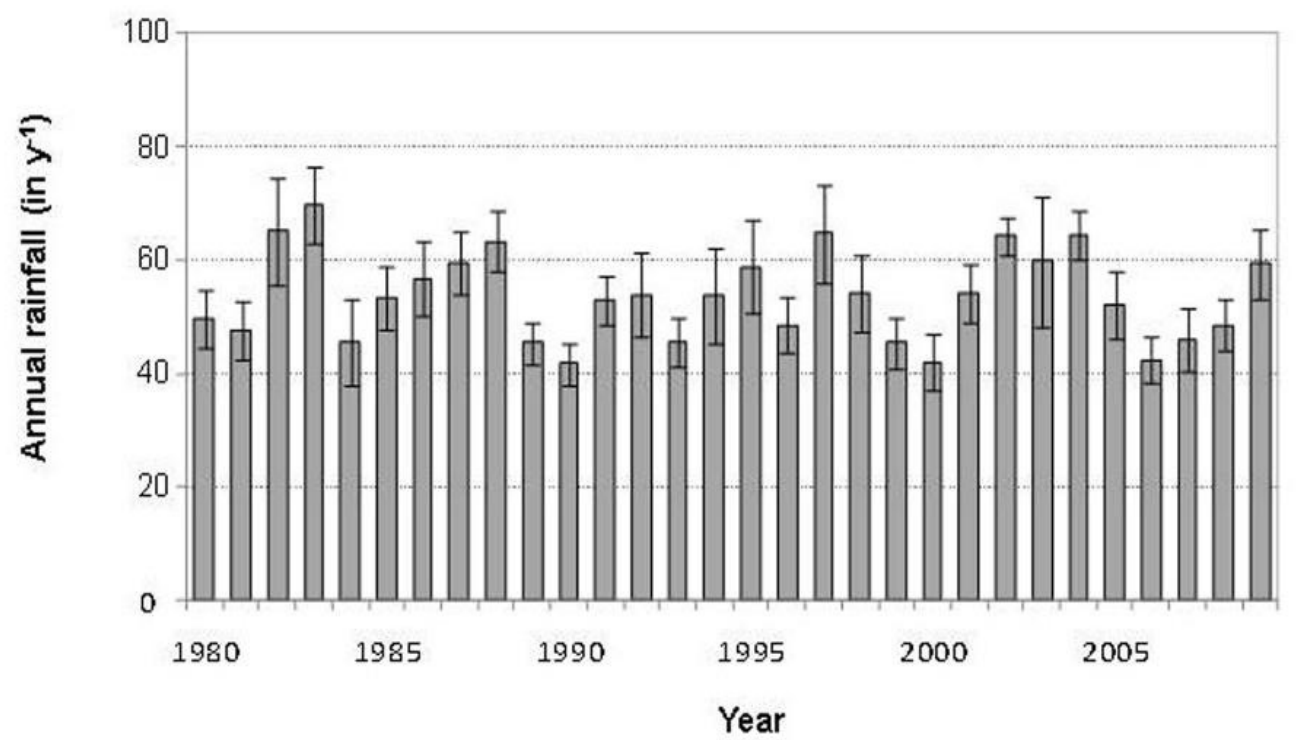

Figure 6. Annual cumulative rainfall for the 30-year period (19802009) of weather station data records in Southwest Florida. Error bars represent the variability of rainfall from 7 rainfall stations. 
Table 4. Daily average difference between minimum temperature and dew point temperature for the 30-year period (1980-2009) of weather station data records.

\begin{tabular}{|c|c|}
\hline Site Location & $\mathbf{T}_{\min }{ }^{-} \mathbf{T}_{\text {dew }}\left({ }^{\circ} \mathbf{C}\right)$ \\
\hline Mobile & 1.8 \\
\hline Tallahassee & 2.2 \\
\hline Jacksonville & 1.9 \\
\hline Gainesville & 1.6 \\
\hline Daytona & 1.6 \\
\hline Orlando & 1.6 \\
\hline Tampa & 1.7 \\
\hline West Palm Beach & 1.8 \\
\hline Fort Myers & 1.4 \\
\hline Miami & 2.0 \\
\hline Key West & 2.4 \\
\hline
\end{tabular}

procedures to show that both measured and calculated data are reasonable. The percentage of missing values was very low for maximum and minimum temperature, and the percentage of missing values for dew point was around $0.01 \%$. The percentage of missing values for rainfall was $0.6 \%$ for most locations except Fort Myers, which had almost $10 \%$ of missing rainfall data.

In the two following EDIS publications in this series, reference evapotranspiration $\left(\mathrm{ET}_{\mathrm{o}}\right)$ is calculated for the same locations using this corrected meteorological database ("Part 2 - Reference Evapotranspiration Calculation"; http://edis.ifas.ufl.edu/ae481), which will then be used with rainfall and other inputs to create daily soil water balances to determine net irrigation requirements for turfgrasses in Florida ("Part 3 - Theoretical Irrigation Requirements"; http://edis.ifas.ufl.edu/ae482).

\section{Acknowledgements}

The authors wish to thank the Southwest Florida Water Management District (SWFWMD) for funding this research. We are also grateful to our four reviewers (K. Migliaccio, C. Martinez, M. McCready, and J. Tichenor) for their valuable comments to the manuscript.

\section{References}

Allen, R.G. 1996. "Assessing Integrity of Weather Data for Reference Evapotranspiration Estimation.” Journal of Irrigation and Drainage Engineering 122(2):97-106. http:// dx.doi.org/10.1061/(ASCE)0733-9437(1996)122:2(97).

Allen, R.G. 1997. "Self-Calibrating Method for Estimating Solar Radiation from Air Temperature." Journal of Hydrologic Engineering 2(2):56-67. http://dx.doi. org/10.1061/(ASCE)1084-0699(1997)2:2(56).

Allen, R.G. 2008. "Quality Assessment of Weather Data and Micrometeorological Flux - Impacts of Evapotranspiration Calculation." Journal of Agricultural Meteorology 64(4):191-204. http://www.jstage.jst.go.jp/article/ agrmet/64/4/191/_pdf.

Allen, R.G., L.S. Pereira, D. Raes, and M. Smith. 1998. Crop Evapotranspiration: Guidelines for Computing Crop Water Requirements. Irrigation and Drainage paper no. 56 ed. Rome, Italy: United Nations Food and Agriculture Organization. http://www.fao.org/docrep/X0490E/ X0490E00.htm.

Allen, R.G., I.A. Walter, R.L. Elliot, and T.A. Howell. 2005. The ASCE Standardized Reference Evapotranspiration Equation. Reston, VA: American Society of Civil Engineers. http://www.kimberly.uidaho.edu/water/asceewri/ascestzdetmain2005.pdf.

Beard, J.B., and M.P. Kenna (eds.). 2006. Water Quality and Quantity Issues for Turfgrasses in Urban Landscapes. CAST Special Publication 27. Ames, Iowa: Council for Agricultural Science and Technology.

Hargreaves, G.H., and Z.A. Samani. 1982. "Estimating Potential Evapotranspiration." Journal of Irrigation and Drainage Engineering 108(3):223-230. http://cedb.asce.org/ cgi/WWWdisplay.cgi?35047.

Irmak, S., J.O. Payero, D.L. Martin, A. Irmak, and T.A. Howell. 2006. "Sensitivity Analyses and Sensitivity Coefficients of Standardized Daily ASCE-PenmanMonteith Equation." Journal of Irrigation and Drainage Engineering 132(6):564-578. http://dx.doi.org/10.1061/ (ASCE)0733-9437(2006)132:6(564).

United States Department of Commerce (USDC). 2009. National Climatic Data Center. Accessed May 31, 2011. http://www.ncdc.noaa.gov. 